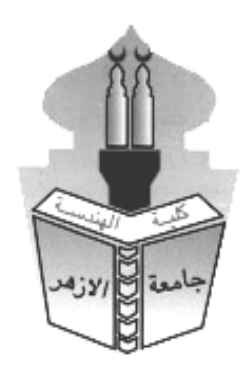

\title{
EVALUATION OF RESPONSE REDUCTION FACTOR FOR REINFORCED CONCRETE ELEVATED WATER TANKS AND CODES, COMPARATIVE STUDY
}

\author{
Nasr E. Nasr ${ }^{1}$, M. N. Fayed ${ }^{2}$, Gamal Hussien ${ }^{3}$, M. I. EL-Far ${ }^{4}$ \\ ${ }^{1}$ Associated Professor of Structural Analysis and Mechanics / Ain shams university, Egypt \\ ${ }^{2}$ Professor of Structural Analysis and Mechanics / Ain shams university, Egypt \\ ${ }^{3}$ Professor of Structural Analysis and Mechanics / Ain shams university, Egypt \\ ${ }^{4}$ Postgraduate Researcher / Ain shams university, Egypt \\ *Corresponding Author E-mail:mohamedehab18@hotmail.com*
}

Received :18 Oct. $2021 \quad$ Accepted:23 Oct. 2021

\begin{abstract}
Reinforced concrete elevated water tanks have been considered as a major element of the water distribution networks. The seismic design loads for this construction, like other structural systems, are based on the concept of permeating plastic deformations during earthquakes to minimise the design elastic force, which is determined by the structure's ability to dissipate induced seismic energy. The values of the $\mathrm{R}$ Factors adopted in the most national and international codes dose not distinguish between several factors like the seismic zones, the vertical and horizontal configuration of framed supporting elements, the response spectrum function type. Thus, the necessity of enhancing the seismic resistance capacity of the elevated tanks is put forward.

This work gives a thorough investigation into the estimation of the Response Modification Factor (R) for raised liquid and water tanks made of reinforced concrete. developed in accordance with Egyptian load code ECP-201 (2012) [1]. Firstly. A verification application of the algorithm of nonlinear pushover analysis is made to compare the outcomes of the application with previously published case study. Then, an comprehensive parametric study is performed on two configurations of R.C. Elevated tanks, considering the variation of the tank height, the seismic zones, the tank capacity, the response spectrum function type comprise 108 case study. The obtained results which is higher than the adopted conservative values in the different codes enhance the understanding of the factors affecting the $\mathrm{R}$ factor.
\end{abstract}

KEYWORDS: Response Reduction Factor (R); Pushover analysis; Nonlinear static analysis; Elevated Concrete Water Tanks, Seismic Zones, Response Spectrum Functions. 


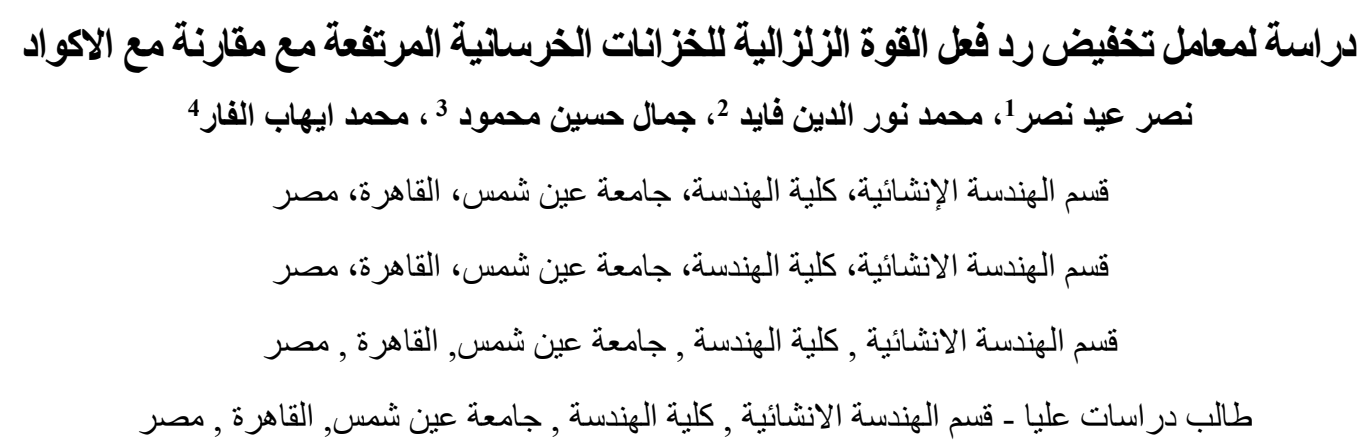

E-mail mohamedehab18@hotmail.com البريد الاليكتروني للباحث الرئيسي:

تعتبر الخزانات الخرسانية المرتفعة عن سطح الأرض أحد العناصر الرئيسية في نظام نقل وتوزيع شبكات المياه ويتم تصميم

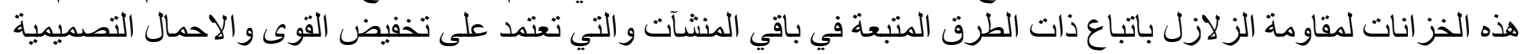

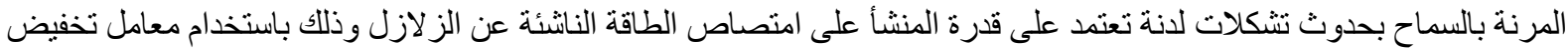

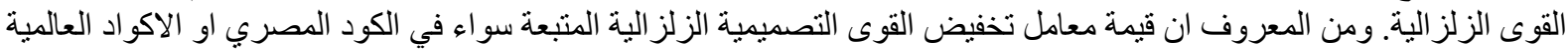

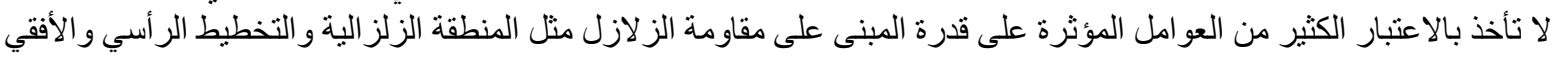

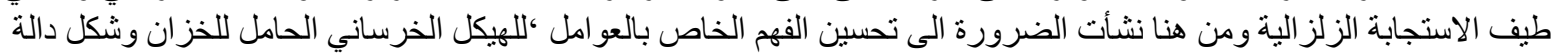

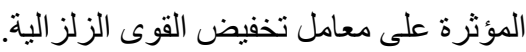

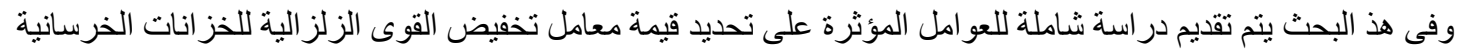

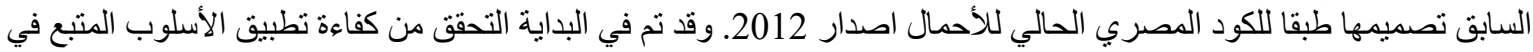

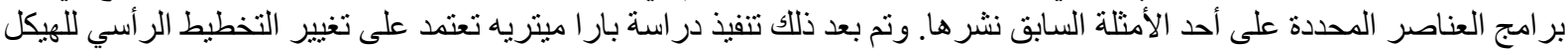

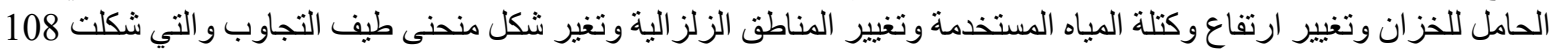

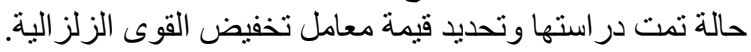

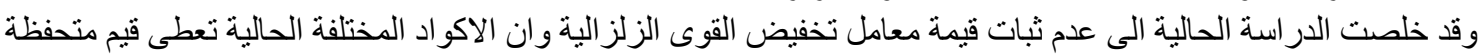

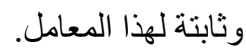

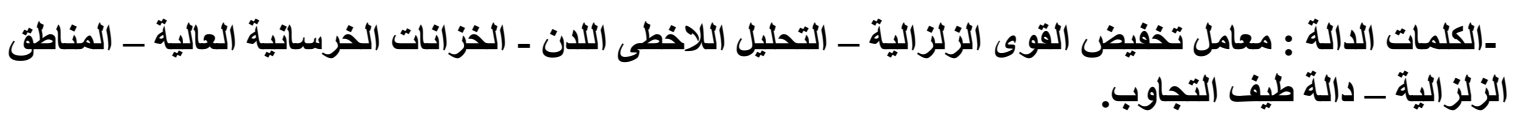

\section{INTRODUCTION:}

The Elevated Water Tanks play very important role in the water distribution systems for the emergency uses such as the firefighting, and the normal uses such that the balancing of pressure for water supply networks and pumps. Because of this critical purpose, these tanks must be completely operational during natural calamities such as earthquakes. Several mishaps involving reinforced concrete water tanks collapsing during previous earthquakes have happened due to poor structural design, ductility, and strength.

The actual codes of practice specify the seismic design criteria for the elevated water tanks which are different than ordinary buildings in some factors. The elevated water tanks, due to there nature and structural systems, have less redundancy, ductility and capability for dissipating the dynamic energy induced by earthquakes than the ordinary buildings. Also, the liquids inside the tanks generate hydrostatic forces and momentum on the walls and skeleton of the supporting structure. As the lateral design seismic loads for elevated water tanks always seem to be higher than regular structures with the same dynamic characteristics due to limited ductility and redundancy.

When a structure is subjected to high seismic excitation, it is said to be shaken. Current seismic design techniques and standards are founded on elastic static loads and dynamic loads modelling, but 
they also take into account inelastic behavior and energy dissipation through the creation of plastic zones and plastic hinges. The so-called force reduction factor, also known as the Response Modification Factor, is the link between elastic and inelastic behavior (R). After dividing the elastic design loads by the factor $\mathrm{R}$, the inelastic seismic design domain is examined, and then the standard elastic domain is used.

During an earthquake, the amount of inelastic demand predicted in building structures is defined by response modification factors $(\mathrm{R})$, which are crucial seismic design tools. According to the various codes, "Response reduction factor," "Response modification coefficient," and "Behavior factor" are all terms for R. R is defined as "Response reduction factor" in IS 1893 (Part 1) [2, "Response modification coefficient" in ASCE 7, and "Behavior factor" in Euro code 8. (q). The R factor is described as "a factor designed to account for both damping and ductility characteristic in structural systems during displacements big enough to reach the maximum displacement" in the discussion to the 1988 National Earthquake Hazards Reduction (NEHRP) [5] criteria. "According to the commentary to the 1988 National Earthquake Hazards Reduction Program (NEHRP) [5] provisions, the R factor can be defined as "factor intended to account for both damping and ductility inherent in structural systems at displacements great enough to reach the systems' maximum displacement." This phrase describes how structures respond to earthquakes and how a code-compliant construction will behave in the case of a design earthquake. The $\mathrm{R}$ factor is a measurement of a structure's inelastic capacity to distribute energy. The $\mathrm{R}$ factor is used in seismic load resisting design to account for damping, energy dissipation capacity, and over strengthening in order to reduce design forces.

Reserve strength and ductility are used by seismic codes to explain this decrease, which enhances the structure's capacity to absorb and distribute energy. As a result, the importance of the force reduction factor, as well as the factors that impact its evaluation and treatment, are essential components of seismic design, according to codes. The FEMA-356 [6] and UBC [7] response modification factor (R) values are meant to account for both reserve strength and ductility. The response modification factor is calculated by ATC [8] as the function of three variables that impact the structure's seismic behavior (Ductility, over strength and redundancy).

Several researches investigate the different aspects control the value of response modification factor of tanks, attempting to enhance the understanding of the prescribed codes recommendations and their real values.

The response modification factor for an RC-framed system raised tank either with or without soil flexibility is compared by Vishva K. Shastri and Jignesh A Amin [9]. The base shear capacity and ductility of existing elevated RC water tanks are evaluated using displacement controlled non-linear static pushover analysis. There were three types of soil conditions considered in this study: hard soil, normal soil, and soft soil. The elasticity of the soil layer has been observed to have a considerable influence on the response modification factor, time period, and overall performance of the water tank, suggesting that idealization of fixity at the base in soft soils may be significantly incorrect.

Jignesh A. Amin and D.P. Soni [10] look at how staging techniques affect realistic response modification factor values for an RC frame staging raised water tank that was built and designed according to Indian norms. Three elevated RC frame staging water tanks with a capacity of $2000 \mathrm{~m} 3$ and a staging height of $16 \mathrm{~m}$, each with a different staging pattern, are designed according to the code for water retaining systems IS 1893 (Part-II) [11], and their base shear capacity and the structure ductility are determined using displacement controlled nonlinear static pushover analysis. According to FEMA356 [6, the response modification factor of the examined RC staging raised water tanks at two level of performance, Performance Limit 1 or PL1 (member level), corresponds to the life safety limit condition of an RC frame member in terms of permitted plastic hinge rotation at member ends. The maximum base shear is defined as the point on the force-displacement relationship curve of structures that corresponds to the second acting Level 2 The structural limit condition PL2 is defined in terms of the structural system's ultimate capability.

By performing linear and nonlinear response history analyses, Mostafa et al. [12] investigate the seismic behaviour and failure processes of Reinforced concrete frame and shaft bearing tanks in severe 
earthquakes while taking $\mathrm{P}$ - effects into account. Ghateh et al. [13] proposed a methodical technique for determining response modification parameters for a total of 48 raised tanks with various capacities and $\mathrm{RC}$ frame dimensions that are routinely utilized in industry. They recommend that tanks with varied staging heights and capacities don't employ the same response reduction factor.

Patel et al. [14], a component-wise response modification for high raised water tanks with same height but varied capacity, was calculated. They came to the conclusion that the value of the response reduction factor for an RC staging tank is impacted considerably by time, tank capacity, and seismic activity.

Mohamed.M, Sherif.S, Hisham.A, and Ezzeldin.Y [15] explore seismic performance variables in raised reinforced concrete tanks, including Over strength factor, Cd ductility factor, and $\mathrm{R}$ response modification factor. Nonlinear static pushover analysis and nonlinear incremental dynamic time history analysis were used to determine and evaluate these factors. Far-Field Maximum Considered Earthquake (MCE) level ground motions compatible with ASCE 7-05 [3] regulations are used to do the nonlinear dynamic time history analysis using three different earthquake data: El-Centro, Parkfield, and Pacoima ground motion. Simplified analysis approaches are used to mimic fluid-structure interaction: Housner's model. Based on the analysis results, the Destruction Index calculated using nonlinear time-history analysis is evaluated to the destruction Index calculated using pushover analysis techniques.

The effect of the seismic zones and idealized response spectrum types, are studied by Hanafy A.H., Darwish M., Baraka M. [16], but the study was applied on framed structures.

In this study, the main factors affecting the value of response modification factor $(\mathrm{R})$ for elevated liquid tanks are investigated. These factors include the height, the tank capacity (mass), the inclination of the columns, the seismic zones, the response spectrum type. 46 models are studied using the finite elements program, (SAP2000) [17], considering these parameters to enhance the understanding of the values of (R) factor.

\section{Response modification factor determination method.}

The response modification factors are the most important design tool for earthquake loads $(\mathrm{R})$, which displays the anticipated inelasticity level in structural systems.

The primary purpose of earthquake engineering is to design a system that can endure an earthquake without completely collapsing, but with significant damage. Similarly, the structure can be tolerated considerably lower base shear pressures than if it kept elastic under intense shaking The relationship between a structure's base-shear and its roof displacement, as well as the formulation of several components of over-stretching factors that may be determined using a nonlinear static analysis, has been [5], as shown in Figure 1

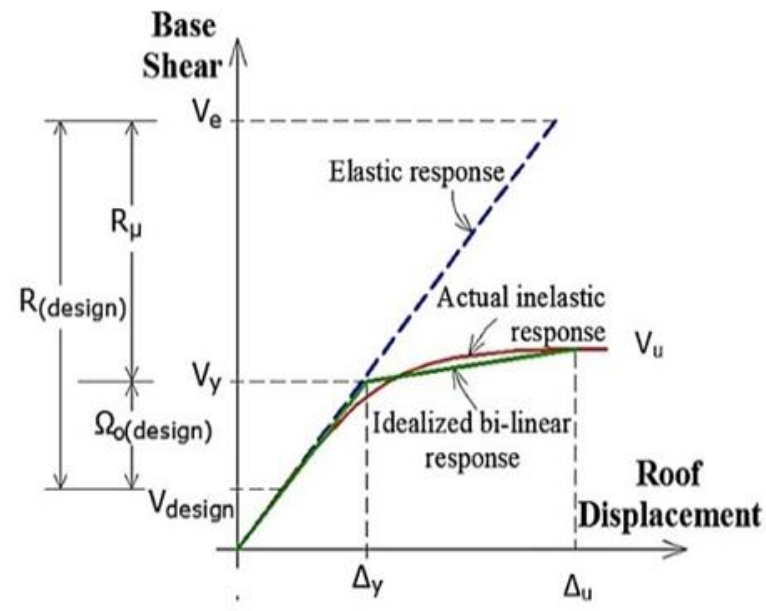

Figure 1: Elastic and inelastic systems' force displacement responses [5]

The major sources of such significant reductions are the Response modification factor, that decreases the elastic needed stress to the structure's yield of the structure, and over strengthing factor, 


\section{EVALUATION OF RESPONSE REDUCTION FACTOR FOR REINFORCED CONCRETE ELEVATED WATER TANKS AND CODES, COMPARATIVE STUDY}

which compensates for the over-strength contained in structural design code. As a result, response modification $(\mathrm{R})$ has the following definition:

$$
\mathrm{R}=\mathrm{R} \mu \times \Omega
$$

\subsection{Factor of over-strengthening}

The over-strength factor is defined as the ratio of actual to design level strength, represented as

$$
\Omega=\mathrm{Vy} / \mathrm{Vd}
$$

$\mathrm{Vd}$ is the design strength, whereas $\mathrm{Vy}$ is strength in yield stage.

The main stream of building over-strengthening includes sequential yield of major aspects, material over-strength, strain hardness, capacity reduction factors, element size, non-structural properties, and specialized ductile details. Elnashai and Mwafy [18]; Rodrigues et al. [19].

\subsection{Ductility Reduction Factor $\mathbf{R} \mu$}

The deformation ductile ratio, " $\mu$ ", FEMA-451 [5], defines amount of in-elastic action of the structural system experiences when exposed to a specific ground movement or lateral stress.

A structure's inelastic acting can be described as:

$$
\mathrm{R} \mu=\Delta \mathrm{u} / \Delta \mathrm{y}
$$

As Response reduction factor is the ratio of ductility of deformations, $u$ defined as ultimate deformation, and $\mathrm{y}$ is yielding deformation.

An idealization of the capacity curve is used to determine yielding displacement and base shear in yield stage.

Factor that reduces the ductility of a material $\mathrm{R}$ is influenced by structural properties including ductility of the system, damping of the structure, and basic period of vibration (T), as well as seismic ground motion characteristics (Maheri and Akbari [20]. In order to determine the Response modification factor, researchers provided different formulas, including R, Newmark, and Hall [21]. The formulation proposed by Newmark and Hall [21] is used in this investigation.

$$
\begin{array}{rrr}
\mathrm{R} \mu & =1.0 & \mathrm{~T} \leq 0.03 \\
\mathrm{R} \mu=1+\frac{(T-0.03) \cdot(\sqrt{(2 \mu-1)}-1)}{0.09} & 0.03<\mathrm{T}<0.12 \\
\mathrm{R} \mu=\sqrt{(2 \mu-1)} & 0.12 \leq \mathrm{T} \leq 0.5 \\
\mathrm{R} \mu=\sqrt{(2 \mu-1)}+2(\mathrm{~T}-0.5) \times(\mu-\sqrt{(2 \mu-1)}) & 0.5<\mathrm{T}<1.0 \\
\mathrm{R} \mu=\mu & \mathrm{T} \geq 1.0
\end{array}
$$

Where $\mu$ is the displacement ductility and $\mathrm{R} \mu$ is the ductility reduction factor.

The target displacement $\delta_{t}$ is calculated from the idealized pushover curve, which can be estimated using ASCE 41-13 [22] coefficient method through the following relation:

$$
\Delta_{\mathrm{u}}=\delta_{t}=C_{0} \mathrm{C}_{1} \mathrm{C}_{2} \mathrm{C}_{3} \mathrm{~S}_{\mathrm{a}} \frac{\mathrm{T}_{\mathrm{e}}{ }^{2}}{4 \pi^{2}} \mathrm{~g}
$$

C 0: spectral displacement of an equivalent SDOF system to roof displacement of the building MDOF system.

C 1: a factor that relates maximum inelastic displacements to displacements predicted for a linear elastic response.

$C$ 2: a modification factor that accounts for the influence of squeezed hysteretic form, stiffness loss, and strength loss on maximum displacement response. 


\section{3: a modification factor that accounts for increased displacements caused by dynamic $P$ - effects.}

Sa: The damping ratio of the structure system in the interest direction, as well like acceleration of response spectrum at the effective fundamental period. Gravitational acceleration is denoted by the letter g.

$\mathrm{T}_{\mathrm{e}}$ : In seconds, the building's effective fundamental duration with in direction under concern.

\subsection{Provision of $\mathbf{R}$ Factor in International Codes.}

Based on the type of building and the structure's ductility grade, the value of the response modification factor in different codes and guidelines ranges from 1.8 to 4.74 . The value of Response reduction factor for Elevated Water Tanks as defined in IBC 2000 [23], FEMA 368 [24], ACI 350-3 [25], AWWA-D100 [26], Eurocode-8 [4], IS 1893-2 [11], and ECP 201[1] are shown in Table 1.

Table 1 : The amount of Response modification adopted in most international codes for Elevated R.C. Water Tanks.

\begin{tabular}{ll|c}
\multicolumn{1}{c|}{ Codes } & $\begin{array}{c}\text { Response Modification } \\
\text { Factor, } R\end{array}$ \\
\hline 1. & \\
& IBC & 3 \\
Supported on Braced and un-Braced legs & 3 \\
Supported on Structural Tower similar to buildings & \\
2. FEMA 368 & $2-3$ \\
Pedestal supported Tanks & $2-4.75$ \\
3. ACI 350-3 & $2-3$ \\
4. AWWA - D100 & $1.8-2$ \\
5. Euro code 8 & 4 \\
6. & \\
7. & \\
ECP 201 & 1.8 \\
Supported Framed Structure with limited ductility & 2.5 \\
Supported Framed Structure with sufficient ductility & \\
\hline
\end{tabular}

\section{NONLINEAR STATIC PUSHOVER ANALYSIS}

The current study used nonlinear static pushover analysis to determine the RC's global limit states. In terms of horizontal displacement and force level, elevated staged liquid tanks. In this study, the growing forcing function is imposed on a structural Finite Element model in terms of horizontal displacements. When the target displacement or final limit state is attained, the analysis is finished. During an earthquake, the target displacement represents the maximum building displacement. This type of analysis can determine the building's maximal strength and deformation capacity. They also aid in the detection of any soft elements in the structure.

In general, nonlinear static analysis is incorporated into the following steps:

Step 1: Create a three-dimensional computerizing model in program.

Step 2: Apply gravitational forces and static lateral forces or deformations in a way that estimate the comparative frictional forces generated at significant mass sites or when each floor's mass is clustered together in the model.

Step 3: Use load pattern case from step 2, move the structure to aimed deformation level. (i.e., the destination node's deformation reaches the target deformation).

Step 4: Calculates each element's forces and deformations at the displacement level that corresponds to the intended displacement.

Step 5: Plot the top displacement versus the base shear.

Performance based seismic design is an alternative approach for analysis and design of buildings. Different codes and standards allow the use of this alternative procedures which based on a well- 
established principle in design and analysis. To obtain a more refined structural behavior incorporating inelastic analysis it is necessary to present the structural seismic response and adequately account for damage loss in both structural and nonstructural elements during earthquakes.

Buildings with established risk and durability standards are produced using performance-based design. (FEMA 356 [6] and ATC 40 [8]). The main goal is to keep the structure from collapsing completely. This means that the higher level will not collapse completely (collapse prevention); the lower level will be somewhat damaged but will be safe to occupy immediately (IO). There is a Life Safety (LS) level that exists between the lower and upper levels. The nonlinear load deformation relation must be defined according to FEMA's nonlinear procedures. Figure 2 shows such a curve.

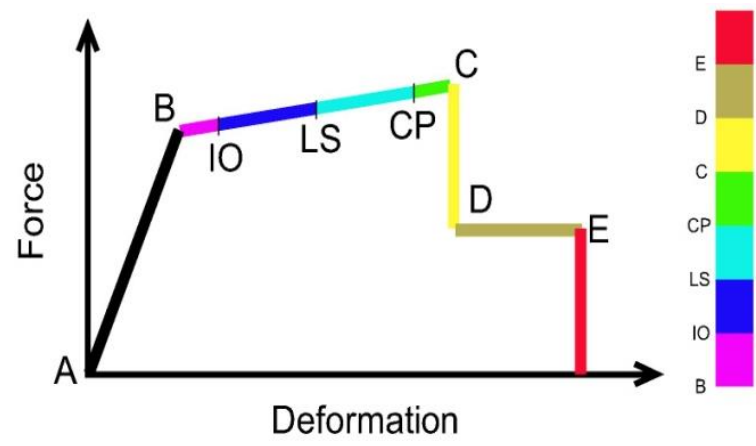

b)

a) .

Figure 2: The typical load-deformation relationship, as well as the desired performance levels [27].

(A, B, C, D, and E) are utilized to characterize the hinge movement behavior of Reinforced concrete components, during FEMA. There are elements define the hinge's approval standards: instant occupancy (IO), life safety (LS), and collapse prevention (CP). The illustrated damage for concrete frames at various levels of structural performance, as indicated in ASCE, 2017b [27].

\section{Verification Application}

To ensure the exact understanding of the algorithm and application of Nonlinear Static pushover analysis to elevated water tanks, one of the previously investigated elevated tanks by Kashyap P, Amin J A [28], which studied this tank through wide investigation of elevated tanks considering the soil flexibility, is examined in this research. The investigated tank has a height of 18 meters, capacity 140 $\mathrm{m} 3$ and number of columns is six, the seismic zone is zone 3, the soil type is medium which chosen in the current application as soil type (C), the full details of the verification case study model data is described in reference [28].

The Elevated Tank configuration is shown in Figure 3. The comparison between the studied case results [28], and the present application of SAP2000, to verify the understanding of the Pushover Nonlinear Analysis is demonstrated in Figure 4 and Table 2. The results show acceptable agreement for the values of response Modification Factor and its components. 


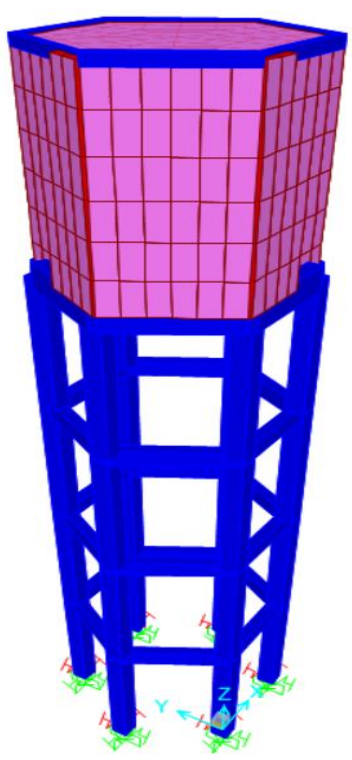

Figure 3: Configuration of studied Elevated Water Tank [28].

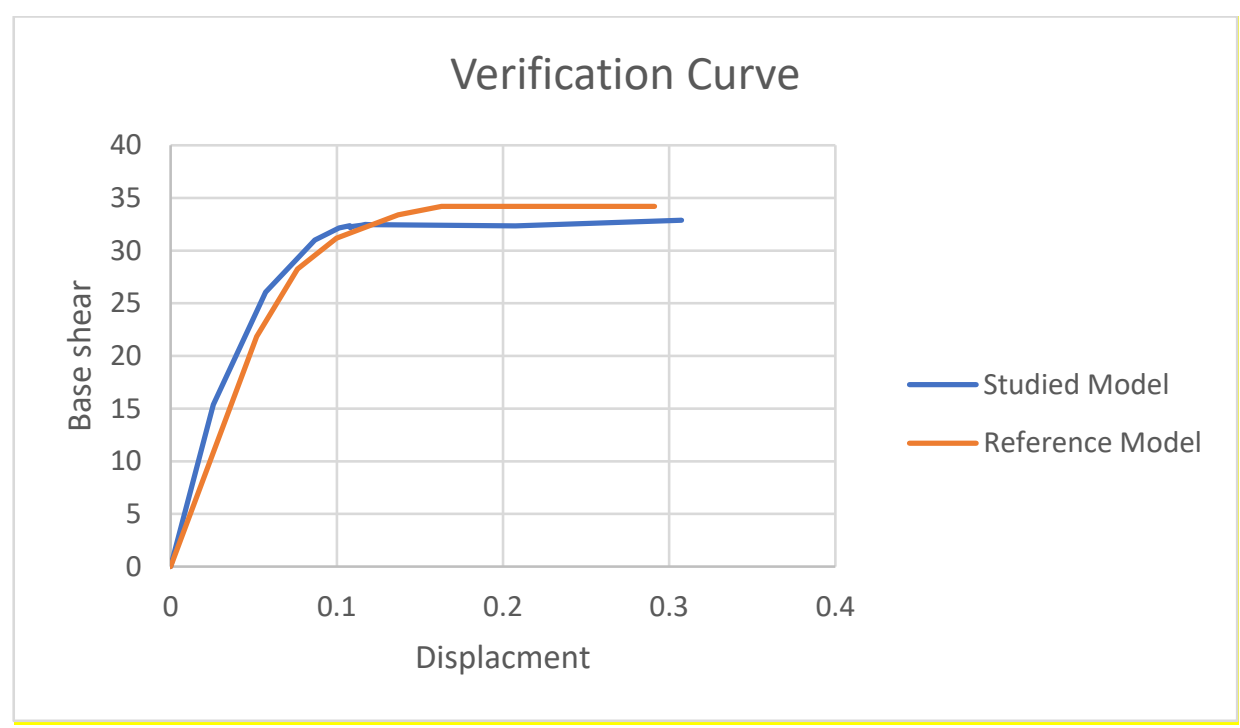

Figure 4: Base shear verses Top displacement

Table 2: R values obtained from SAP2000 and Ref. [28].

\begin{tabular}{c|ccccc}
\hline Column1 & T(Second) & $\begin{array}{c}\text { Deformation } \\
\text { yield }\end{array}$ & $\begin{array}{c}\text { Deformation } \\
\text { Ultimate }\end{array}$ & $\begin{array}{c}\text { Base Shear } \\
\text { Yield }\end{array}$ & $\begin{array}{c}\text { Base shear } \\
\text { Ultimate }\end{array}$ \\
\hline $\begin{array}{c}\text { Reference } \\
{[28]}\end{array}$ & 1.36 & 0.078 & 0.281 & 30 & 35 \\
$\begin{array}{c}\text { Present } \\
\text { application }\end{array}$ & 1.68168 & 0.0574 & 0.237 & 30.64 & 32.513 \\
\hline
\end{tabular}




\section{PARAMETRIC STUDY FOR RESPONSE MODIFICATION FACTOR OF ELEVATED WATER TANKS}

In this part of the current study, elevated tanks with two different configuration of columns (vertical and inclined), 3 different heights, 3 different capacities, 3 different seismic zones and two types of response spectrum functions as per Egyptian code of loads, ECP201 [1]. The main characteristics parameters of the studied tanks in the present work are summarized in the Figure [5] and table [3].

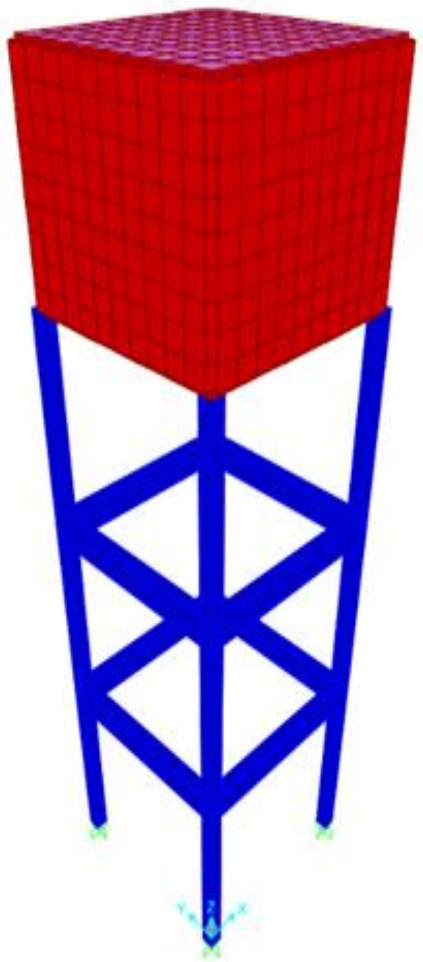

(a) Vertical Tank

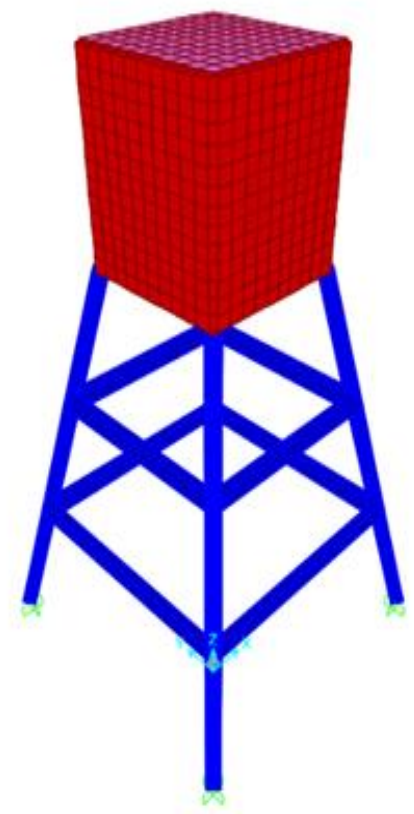

(b) inclined tank with 11.31 degree

Figure 5: Configurations of studied Elevated water Tank with vertical and inclined columns.

Table 3: different parameters of the studied elevated tanks.

\begin{tabular}{c|ccccc}
\hline $\begin{array}{c}\text { Number of } \\
\text { studied } \\
\text { Models }\end{array}$ & Seismic Zones & $\begin{array}{c}\text { Vertical } \\
\text { Alignment } \\
\text { of columns }\end{array}$ & $\begin{array}{c}\text { Tanks } \\
\text { Capacities } \\
\text { ton) }\end{array}$ & $\begin{array}{c}\text { Heights } \\
(H)\end{array}$ & $\begin{array}{c}\text { Response } \\
\text { spectrum Types }\end{array}$ \\
\hline 108 & Z3-Z4-Z5 & $\begin{array}{l}\text { Vertical(V) } \\
\text { Inclined (I) }\end{array}$ & $\begin{array}{c}50-100- \\
150\end{array}$ & $10-15-30$ & Type 1 \\
& & & Type 2 \\
\hline
\end{tabular}

The parametric study matrix with all possible combinations results out 108 models for tanks. The 108-case study with different parameters were designed according to the Egyptian codes for all the loads combinations to obtain an optimum design with stresses ratio between demands and maximum capacity about $(0.80-0.90)$. This means that the concrete dimensions and the reinforcement ratio of the structural elements are not constant and it had to change to satisfy to target stresses ratio. 


\section{EVALUATION OF RESPONSE REDUCTION FACTOR FOR REINFORCED CONCRETE ELEVATED WATER TANKS AND CODES, COMPARATIVE STUDY}

The side dimensions of square columns vary from $400 \mathrm{~mm}$ to $600 \mathrm{~mm}$ according to the height, tank volume, seismic zone. Also, the bonding beams, the floor thickness, the wall thickness as well the reinforcement ratio had to change to obtain optimum design. All of these tanks were designed to withstand both gravity and seismic loads as specified by ECP 201 [1]. Table 4 summarize the average characteristic values for all the design data for 108 studied cases of tanks.

Table 4: Average Dimensions and Reinforcement of all cases of study.

\begin{tabular}{|c|c|c|c|c|c|c|c|}
\hline \multirow{4}{*}{$\begin{array}{c}\text { Structural } \\
\text { Element }\end{array}$} & \multirow{3}{*}{$\begin{array}{c}\text { Dimensions \& } \\
\text { Raft. }\end{array}$} & \multicolumn{6}{|c|}{$F c u=400 \mathrm{~kg} / \mathrm{cm}^{2}, A v g$. Dimension and Avg. Raft. } \\
\hline & & \multicolumn{3}{|c|}{ Vertical Columns } & \multicolumn{3}{|c|}{ Inclined Columns $\left(11.31^{\circ}\right)$} \\
\hline & & $\mathrm{H}=10 \mathrm{~m}$ & $\mathrm{H}=15 \mathrm{~m}$ & $\mathrm{H}=30 \mathrm{~m}$ & $\mathrm{H}=10 \mathrm{~m}$ & $\mathrm{H}=15 \mathrm{~m}$ & $\mathrm{H}=30 \mathrm{~m}$ \\
\hline & $\begin{array}{l}\text { Dimensions } \\
\quad(\mathrm{mm})\end{array}$ & $500 * 500$ & $500 * 500$ & $500 * 500$ & $500 * 500$ & $500 * 500$ & $500 * 500$ \\
\hline \multirow[t]{6}{*}{ Columns } & Main & 10T20, & 10T20, & 10T20, & 10T20, & $10 \mathrm{~T} 20$, & 10T20, \\
\hline & Reinforcement & $\begin{array}{c}12 \mathrm{~T} 16, \\
14 \mathrm{~T} 16\end{array}$ & $\begin{array}{c}14 \mathrm{~T} 16, \\
16 \mathrm{~T} 16\end{array}$ & $\begin{array}{l}\text { 14T16, } \\
16 \mathrm{~T} 16\end{array}$ & $\begin{array}{c}12 \mathrm{~T} 16, \\
14 \mathrm{~T} 16\end{array}$ & $\begin{array}{c}14 \mathrm{~T} 16, \\
16 \mathrm{~T} 16\end{array}$ & $\begin{array}{c}\text { 14T16, } \\
16 \mathrm{~T} 16\end{array}$ \\
\hline & Stirrups & Y8@100 & Y8@100 & Y8@100 & Y8@100 & Y8@100 & Y8@100 \\
\hline & $\begin{array}{l}\text { Dimensions } \\
\quad(\mathrm{mm})\end{array}$ & $300 * 700$ & $300 * 700$ & $300 * 700$ & $300 * 700$ & $300 * 700$ & $300 * 700$ \\
\hline & Bottom & 2T16, 5T16 & $3 \mathrm{~T} 16,6 \mathrm{~T} 16$ & $4 \mathrm{~T} 16,7 \mathrm{~T} 16$ & $2 \mathrm{~T} 16,5 \mathrm{~T} 16$ & $3 \mathrm{~T} 16,6 \mathrm{~T} 16$ & $4 \mathrm{~T} 16,7 \mathrm{~T} 16$ \\
\hline & Reinforcement & , 6T16 & , 7T16 & , 8T16 & , 6T16 & , 7T16 & , 8T16 \\
\hline \multirow[t]{2}{*}{ Beams } & $\begin{array}{c}\text { Top } \\
\text { Peinfor }\end{array}$ & $2 \mathrm{~T} 16$ & $3 \mathrm{~T} 16$ & $4 \mathrm{~T} 16$ & $3 \mathrm{~T} 16$ & $3 \mathrm{~T} 16$ & $5 \mathrm{~T} 16$ \\
\hline & Stirrups & Y8 @ 150 & Y8 @ 150 & Y8@150 & Y8@150 & Y8@150 & Y8 @ 150 \\
\hline \multirow{4}{*}{$\begin{array}{l}\text { Tank } \\
\text { Floor }\end{array}$} & Thickness & 250 & 250 & 250 & 250 & 250 & 250 \\
\hline & Reinforcement & 7T12 $6 \mathrm{~T} 16$ & 7T12 6T16 & $7 \mathrm{~T} 12 \quad 6 \mathrm{~T} 16$ & 7T12 6T16 & $7 \mathrm{~T} 12 \quad 6 \mathrm{~T} 16$ & $7 \mathrm{~T} 12 \quad 6 \mathrm{~T} 16$ \\
\hline & Кептотестит & , 7T18 & 7Т18 & , 7T18 & , 7T18 & , 7T18 & , 7T18 \\
\hline & $\begin{array}{c}\text { Thickness } \\
\text { (mm) }\end{array}$ & $250,400,600$ & $250,400,600$ & $250,400,600$ & $250,400,600$ & $250,400,600$ & $250,400,600$ \\
\hline \multirow{2}{*}{$\begin{array}{l}\text { Tank } \\
\text { wall }\end{array}$} & vertical & 7T12, 6T16 & 7T12, 6T16 & 7T12, 6T16 & 7T12, 6T16 & 7T12, 6T16 & 7T12, 6T16 \\
\hline & $\begin{array}{l}\text { Reinforcement } \\
\text { horizontal } \\
\text { Reinforcement }\end{array}$ & $\begin{array}{c}, 7 \mathrm{~T} 18 \\
5 \mathrm{~T} 12,5 \mathrm{~T} 16\end{array}$ & $\begin{array}{c}, 7 \mathrm{~T} 18 \\
5 \mathrm{~T} 12,5 \mathrm{~T} 16\end{array}$ & $\begin{array}{c}, 7 \mathrm{~T} 18 \\
5 \mathrm{~T} 12,5 \mathrm{~T} 16\end{array}$ & $\begin{array}{c}, 7 \mathrm{~T} 18 \\
5 \mathrm{~T} 12,5 \mathrm{~T} 16\end{array}$ & $\begin{array}{c}, 7 \mathrm{~T} 18 \\
5 \mathrm{~T} 12,5 \mathrm{~T} 16\end{array}$ & $\begin{array}{c}, 7 \mathrm{~T} 18 \\
5 \mathrm{~T} 12,5 \mathrm{~T} 16\end{array}$ \\
\hline
\end{tabular}

Performance based design are applied on the elevated tanks using Nonlinear static pushover analysis performed using SAP2000 Package, as per ATC-40 and FEMA 356. Plastic hinges are assigned at the locations where yielding is expected under seismic forces at both ends of the beams and columns with start and end relative distances of 0.05 and 0.95 respectively with (M3) type for beams and (P-M2M3) type for columns as per ASCE 41-13. Nonlinear static gravity load case; containing full values for each of own weight, super dead load and live load with zero initial condition, the mass source resulted from the gravity loads (Dead Load + Super Dead Load + Live Load) are employed. Nonlinear static pushover load cases in global X-Direction with static lateral load pattern is applied to the structure starts from the end of the nonlinear gravity load case with target displacement equal $4 \%$ from the total building height. 


\section{RESULTS AND DISCUSSION}

For each one of the 108 studied tanks, and after performing the optimum design cycle followed by the pushover analysis, the relation between the maximum base shear can sustained by the tanks and the maximum top displacement are obtained and plotted inherently through SAP2000. It should be taken into consideration that the structure had passed through the three performance levels (IO-LS-CP), as per ATC-40, the components of Response Modification Factor (R), which consist of the over-strength factor $(\Omega)$ and ductility reduction factor $(\mathrm{R} \mu)$ are calculated.

For the purpose of quantitative evaluation of the obtained results, the $\mathrm{R}$ values for the studied cases are collected on the bar charts demonstrated in Fig. 6 to Fig. 11 for response spectrum type 1 and from Fig. 12 to Fig. 17 for response spectrum type 2. Each family of these curves covers the tanks height, capacity, seismic zones and vertical configuration. From these graphs, the values of $\mathrm{R}$ factors obtained for type 1 spectrum functions is a higher than type 2 considering the rest of the four parameters are kept unchanged.

The results shown that in general for all seismic zones, the increasing of height of tanks, decreasing the value of $\mathrm{R}$ Factor. Also, the capacity effect of the tanks results in an increase of the $\mathrm{R}$ factor, as the increase of mass and weight require a bigger columns cross section to maintain the safety levels for design purpose.

The inclination of the tank-columns results in a little decrease in the $\mathrm{R}$ value which is understandable due to the effect of normal forces which raise the cross-section capacity. Also, as a quantitative analysis of the results, as the seismic ground acceleration increase, the $\mathrm{R}$ factor increase which due to the fact that the cross sections have a higher capacity.

Finally, it's important to highlights that the values of $\mathrm{R}$ factors are higher than the recommended values in the different codes-(Table 1) ranging from 4-5, for studied low rise tanks $(\mathrm{H}=10 \mathrm{~m})$ while for medium height studied tanks $(\mathrm{H}=15)$, these values ranging from 3-4, and for tanks of height $(\mathrm{H}=30)$, the $\mathrm{R}$ values are in the same range of the codes (ranging from 2-4), which explain the conservative values of $\mathrm{R}$ Factors recommended by most of the national and international codes.

(N.B: The key number in graphs designate1 for Height $10 \mathrm{~ms}, 2$ for Height $15 \mathrm{~ms}$ and 3 for Height 30 $\mathrm{ms})$. 
EVALUATION OF RESPONSE REDUCTION FACTOR FOR REINFORCED CONCRETE ELEVATED WATER TANKS AND CODES, COMPARATIVE STUDY

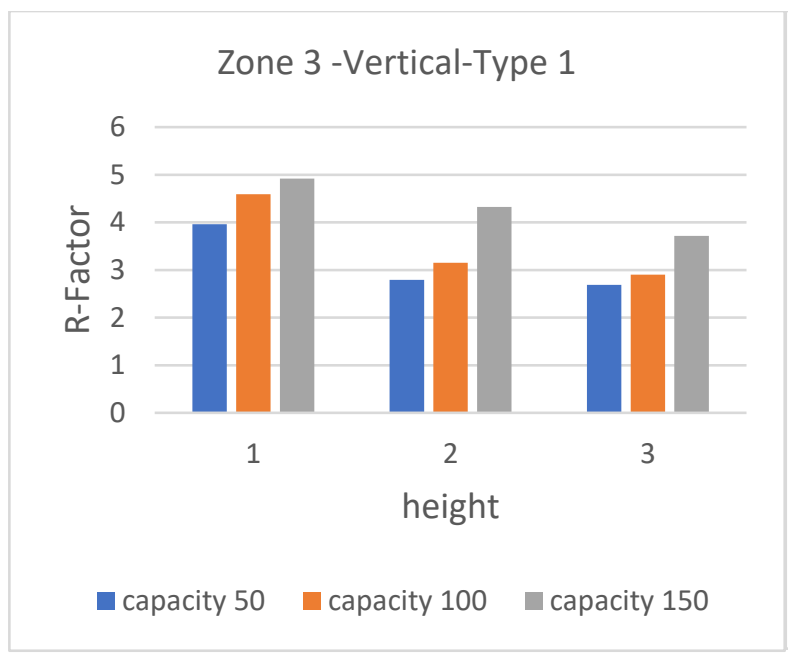

Figure 6: Zone 3 Vertical Type 1 R-Factor value

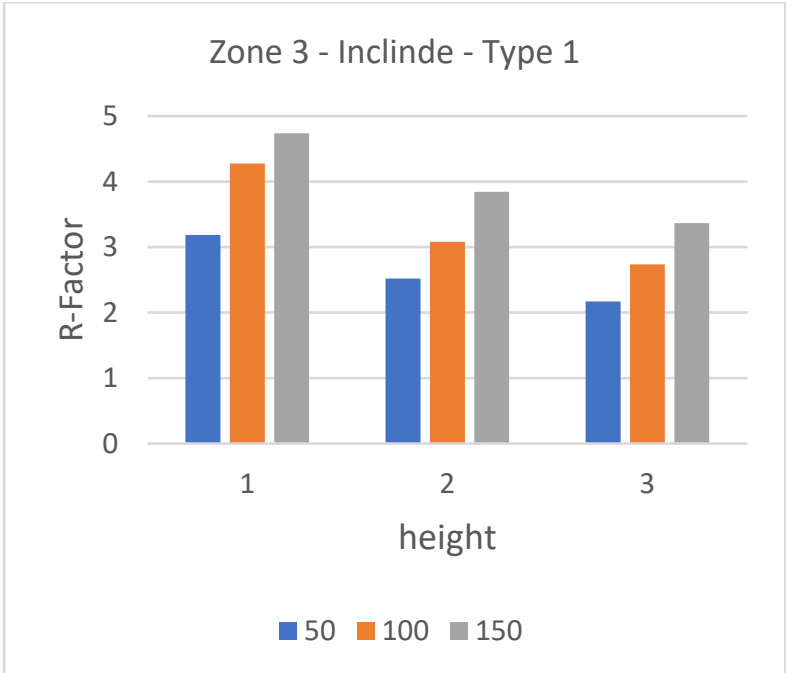

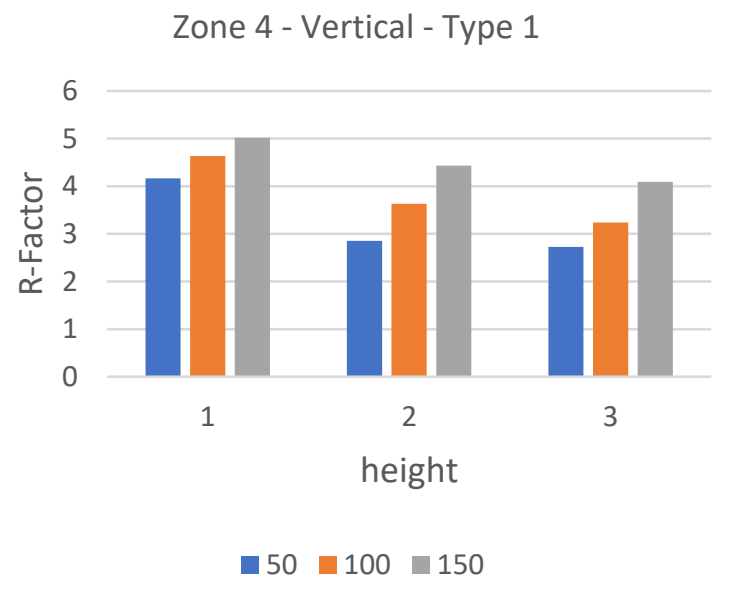

Figure 7: Zone 4 Vertical Type 1 R-Factor value

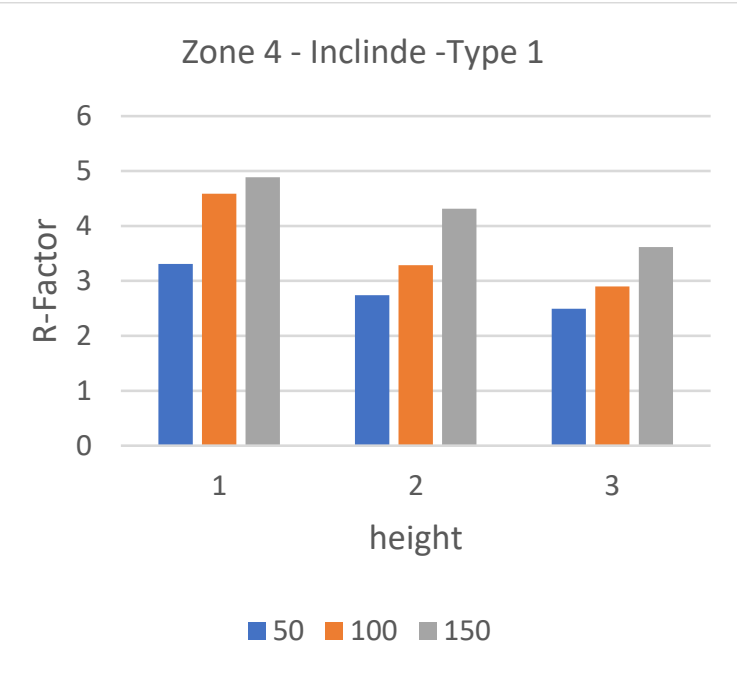

Figure 8: Zone 3 Inclined Type 1 R-Factor value Zone 5 -vertical -Type 1

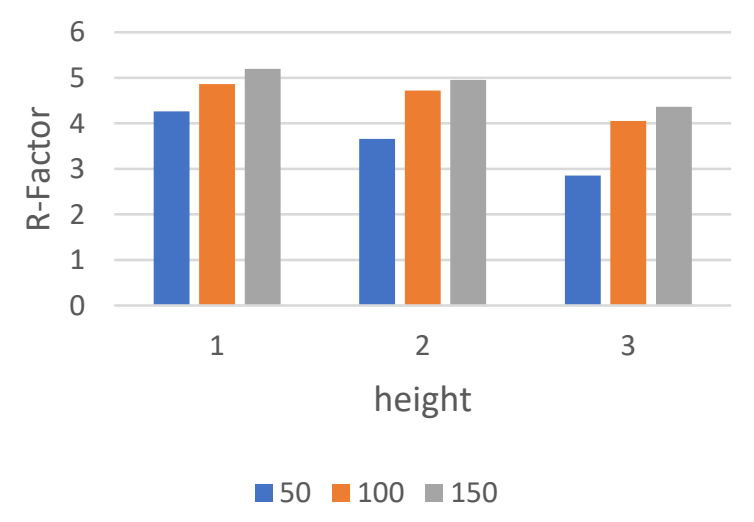

Figure 9: Zone 4 Inclined Type 1 R-Factor value

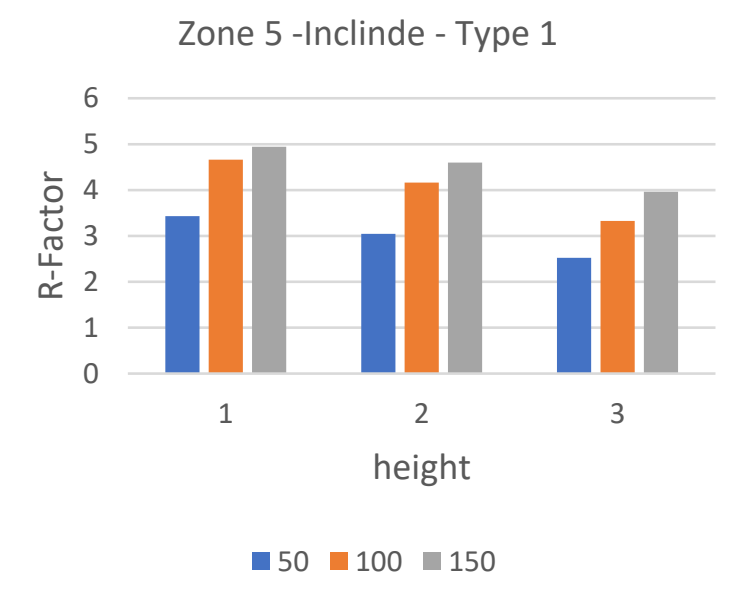

Figure 10: Zone 5 Vertical Type 1 R-Factor value

Figure 11: Zone 5 Inclined Type 1 R-Factor value 


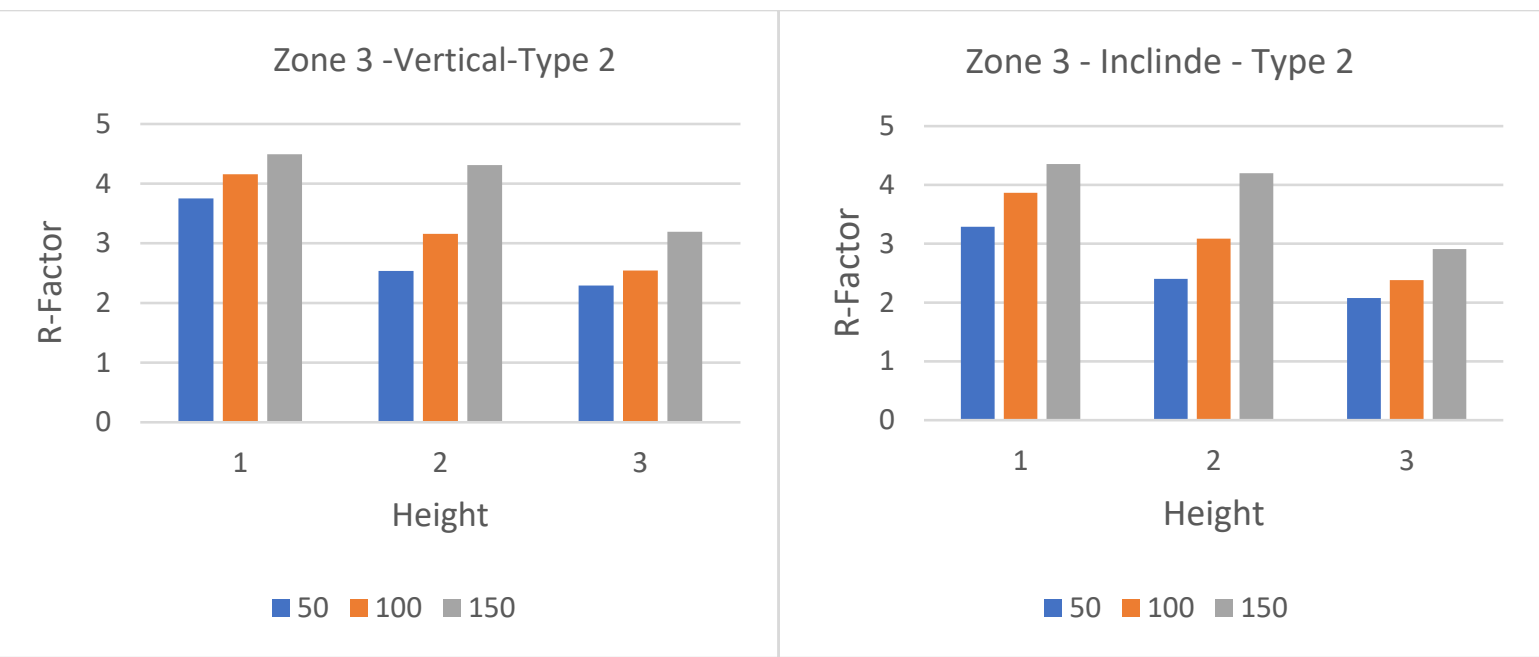

Figure 12: Zone 3 Vertical Type 2 R-Factor value

Figure 13: Zone 4 Vertical Type 2 R-Factor value
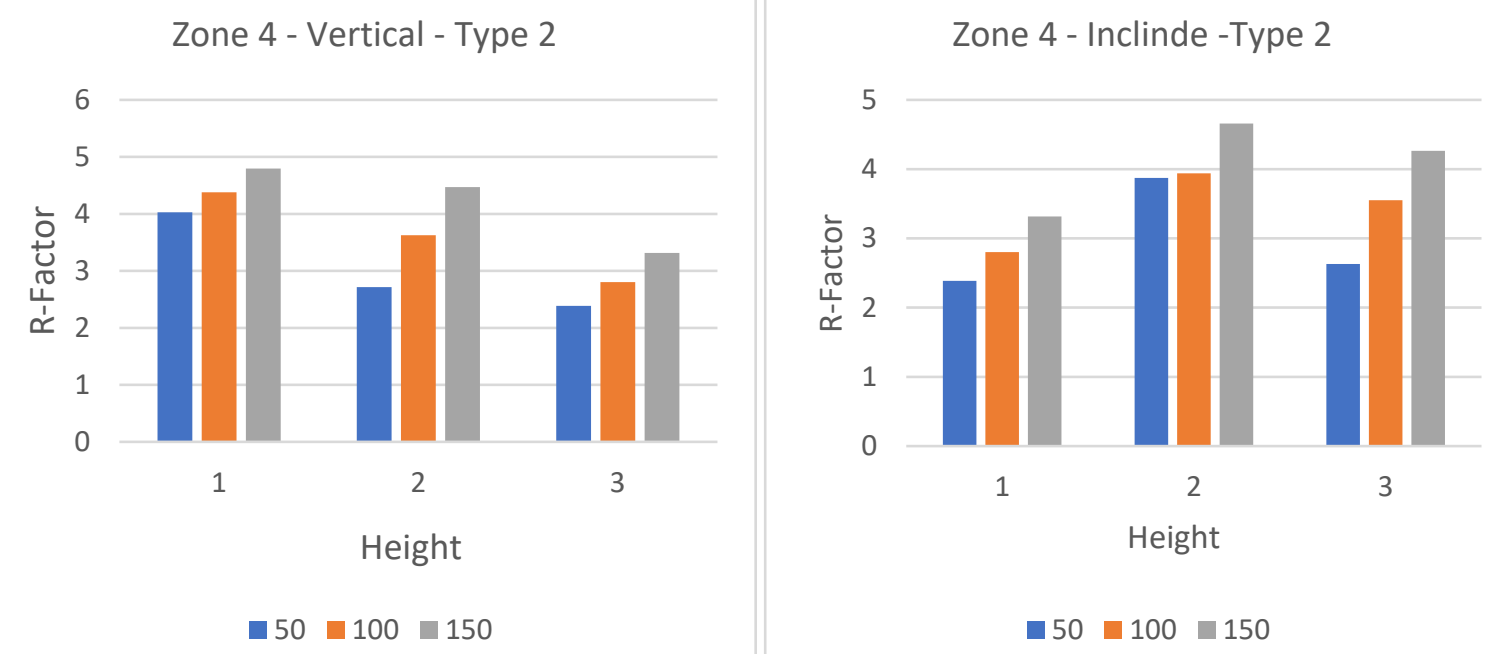

Figure 14: Zone 3 Inclined Type 2 R-Factor value

Figure 15: Zone 4 Inclined Type 2 R-Factor value
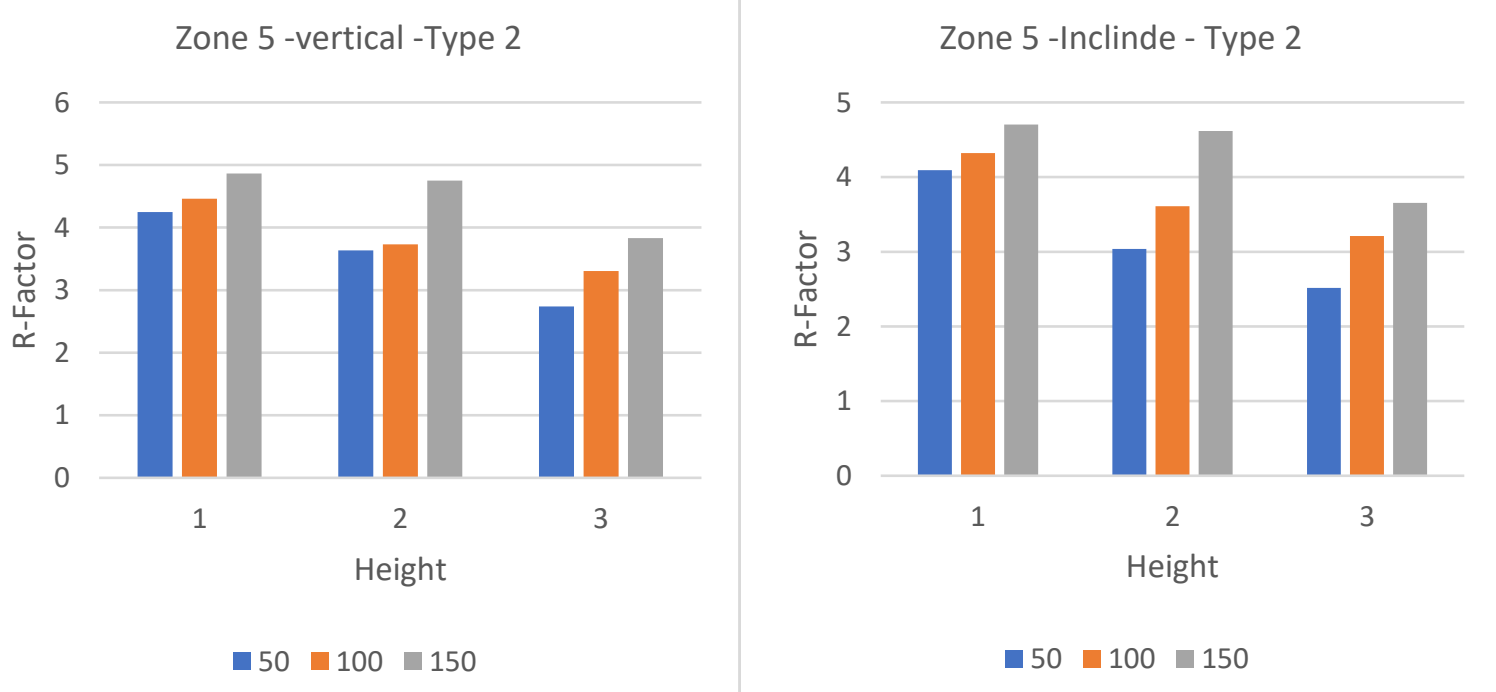

Figure 16: Zone 5 Vertical Type 2 R-Factor value

Figure 17: Zone 5 Inclined Type 2 R-Factor value

\section{CONCLUSIONS}

This research presents a comprehensive parametric study for the Response Modification Factor (R) for Elevated water tanks designed for seismic loads according to the ECP201 satisfying the optimum 
design conditions. The 108 models studied using the pushover technique covers five main parameters controlling the seismic behavior of elevated tanks. The study outcomes indicates that the $\mathrm{R}$ values not constant for all heights, depending on the mass of water, also depends on the configuration of tank framing columns, seismic zones and no strong correlation with response spectrum functions types. The study agrees with the most national and international codes for the $\mathrm{R}$ values for higher tanks but for low rise tanks, the current codes are conservative.

\section{REFERENCES}

1. ECP (2012) ECP-201: Egyptian code for calculating loads and forces in structural work and masonry. Housing and Building National Research Center. Ministry of Housing, Utilities and Urban Planning, Cairo

2. I.S. 1893 (2002): "Indian Standard Criteria for Earthquake Resistant Design of Structures Part 1: General Provisions and Buildings", Bureau of Indian Standards, New Delhi.

3. ASCE SEI/ASCE 7-05 (2005). Minimum design loads for buildings and other structures. Reston (USA): American Society of Civil Engineers.

4. EC8 (2004), "Design of structures for earthquake resistance" Part 1: General rules, Seismic action and rules for buildings. European Committee for Standardization, Brussels, Belgium.

5. Federal Emergency Management Agency (FEMA), (1999) "NEHRP Recommended Provisions for Seismic Regulations for New Buildings 2005 Edition” (FEMA 451), Washington, DC, July 2005125, April 1999.

6. Federal Emergency Management Agency (FEMA), (1997) "Pre standard and Commentary for the Seismic Rehabilitation of Buildings" (FEMA 356), Washington, DC, October 1997.

7. Uniform Building Code (UBC 1997). Structural Engineering Design Provisions.

8. ATC -40 (1996) "Seismic Response Modification Factors" Applied Technology Council (ATC), Redwood City, California.

9. Vishva K. Shastri, Jignesh A Amin, (2015) "Effect of Soil Condition on Response Reduction Factor of Elevated RC Water Tanks" International Journal of Advance Engineering and Research.

10. Jignesh A. Amin and D.P.Soni (2017) “Assessment Response Reduction Factor of Elevated Tanks with Alternate RC Frame Staging Configurations" International Journal of Engineering Technology Science and Research, IJETSR, ISSN 2394 - 3386, Volume 4, Issue 12.

11. I.S. 1893 (2014): "Indian Standard Criteria for Earthquake Resistant Design of Structures Part 2: General Provisions and Buildings", Bureau of Indian Standards, New Delhi.

12. Mostafa M, Sassan E, Mohsen G (2012), Evaluation of Response Modification Factor (R) of Elevated Concrete Tanks, Eng. Struct.,39:199-209.

13. Ghateh R, Kianoush M.R and Pogorzelski W., (2015) "Seismic response factor of RC pedestal in elevated water tanks" Engineering Structures, Vol-87, pp. 32-46, 2015.

14. Patel T.Amin J A, Patel B (2014), “Evaluation of Response Reduction Factor of R.C. Framed Staging Elevated Water Tanks Using Static Pushover Analysis", Int. J. Cicil Struct. Eng.4 (3):215-226.

15. Mahmoud M, Sherif S, Hisham A, Ezzeldin Y, (2015), "Evaluation of Seismic Performance Factors for Elevated Reinforced Concrete Tanks", Available: https://www.researchgate.net/publication/263453627.

16. Hanafy A.H., Darwish M., Baraka M. (2017) "Egyptian Code Seismic Load Design Provisions for Moment Resisting Frames" In: Rodrigues H., Elnashai A., Calvi G. (eds) Facing the Challenges in Structural Engineering. Geo M East, Sustainable Civil Infrastructures. Springer, Cham. 
17. Computer \& Structures Inc. Structural Analysis Programs, SAP 2000, Computer Software Package. California: CSI Inc. 2005.

18. Elnashai,A.S and A.M. Mwafy, (2002) "Calibration of Force reduction factors for RC Building” Journal of Earthquake Engineering, Vol. 6, No. 2, 239-273.

19. Rodrigues H, Arede A, Varum, H. and Costa, A. (2012a), "Comparative Efficiency Analysis of Different Nonlinear Modeling Strategies to Simulate the Biaxial Response of RC Columns," Earthquake Engineering and Engineering Vibration, 11: 553-566.

Available: https://link.springer.com/content/pdf/10.1007/s11803-012-0141-1.pdf

20. Maheri, M.R. and Akbari, R. (2003). "Seismic behavior factor, R, for steel X-braced and knee-braced RC buildings", Engineering Structures, 25,1505-1513.

Available: https://www.sciencedirect.com/science/article/pii/S0141029603001172.

21. Newmark NM and Hall WJ (1973), "Seismic Design Criteria for Nuclear Reactor Facilities," Report No 46, Building Practices for Disaster Mitigation, National Bureau of Standards, U.S. Department of Commerce. Available: http://www.iitk.ac.in/nicee/wcee/article/4_vol2_B4-37.pdf.

22. ASCE 41-13, 2013 Publication Anticipated Seismic Evaluation and Upgrade of Existing Buildings, American Society of Civil Engineers, Reston, Virginia. Public Comment Edition available through the American Society of Civil Engineers.

23. IBC (2018) International building Code, International Code Council.

24. FEMA368, (2000) "NEHRP Recommended Provisions for New Building and other Structures -Part 1: Provisions Building Seismic Safety Council, Washington, DC, USA.

25. ACI 350.3 (2001) "Seismic Design of Liquid Containing Concrete Structures", American Concrete Institute Standards, Farmington Hills.

26. AWWA-D110 (1995) Wire and Strand - Wound Circular Prestressed Concrete Water Tanks. American Water Work Association, Colorado, USA.

27. ASCE. (2017b). Seismic Evaluation and Retrofit of Existing Buildings. Seismic Evaluation and Retrofit of Existing Buildings. American Society of Civil Engineers, Reston, Virginia

28. Kashyap P, Amin J A, (2018), “ Performance-Based Assessment of Response Reduction Factor of R.C. Elevated Water Tanks Considering Soil Flexibility: A Case Study. ", Int. J. of Advanced Structural Engineering $10: 233-247$. 